\title{
Influence of dietary fatty acids and fat level on morphological changes in the liver of nase (Chondrostoma nasus L.) $^{*}$
}

\section{T. Ostaszewska' and E. Sawosz ${ }^{2}$}

\author{
Warsaw Agricultural University, \\ 'Division of Ichthyobiology and Fisheries, \\ ${ }^{2}$ Department of Animal Nutrition and Feed Science \\ Ciszewskiego 8, 02-786 Warsaw, Poland
}

\section{ABSTRACT}

The aim of the present study was to evaluate the effects of a high level of dietary fat and polyunsaturated fatty acids on growth rate, survival and liver morphology of nase larvae (Chondrostoma nasus L.). The results indicated that $16 \%$ of fat in feed, excessive supply of $22-$ carbon PUFA, and insufficient amount of MUFA may disturb lipid homeostasis in the hepatocytes of freshwater fish, and adversely affect fish growth.

KEY WORDS: Chondrostoma nasus L., fish. larval nutrition, lipids, fatty acids, liver histology

\section{INTRODUCTION}

The feeding of fish larvae, especially at the time of the change from endogenous to exogenous feed, is the most critical moment in fish rearing. After resorption of the yolk sac, exogenous feed becomes the only source of nutrients and energy. Insufficient as well as excessive amounts of fat or unbalanced essential fatty acid (EFA) composition results in high larval mortality, reduced growth rate, body deformation and morphological anomalies (Tacon, 1996). According to Caballero et al. (1999), an increase in the dietary fat level improved the growth rate of adult fish. However, little data is available on the effect of dietary lipid and fatty acids on growth of freshwater fish larvae.

The nase (Chondrostoma nasus L.) is a reophilous fish, and used to be common in many European rivers. At present, the nase is a strongly endangered species. Artificial reproduction and rearing of nase juveniles on commercial feeds is the only possibility of increasing nase populations.

\footnotetext{
"Supported by the State Committee for Scientific Research, Grant No. 3 PO6Z 02724 (2003/06)

${ }^{2}$ Corresponding author: e-mail: sawosz@alpha.sggw.waw.pl
} 
The aim of the present study was to evaluate the effects of a high level of dietary fat and polyunsaturated fatty acids on growth rate, survival and liver morphology of nase larvae (Chondrostoma nasus L.).

\section{MATERIAL AND MEDHODS}

The fish were placed in recirculatory $20 \mathrm{dm}^{3}$ aquaria, at a stocking density of 70 ind $\mathrm{dm}^{3}$. The larvac were divided into three experimental groups (three replicates in cach), and fed from day 4 to 60 from hatching: control (A) - with Artemia sp. nauplii, group B - with Aller Uni starter (Allter Aqua Allervej, Denmark); group $C$ - with Nutra $A B$ 3.0 (Trouvit, Nutreco Aquaculture, The Netherlands). The isoproteinous feeds contained 11,7 and $16 \%$ fat, respectively. The fatty acid composition of the dicts is shown in Table 1. During the experiment, the larvae were sampled for liver ultrastructure analyses. Samples were prepared using standard methods and were observed on using a Joel JEM $100 \mathrm{C}$ transmission microscope. The size of hepatocyte nuclei, cyloplasm volume, amount of lipid and glycogen in the cells, shape of the milochondria were determined.

\section{RESULTS}

The diets $B$ and $C$ resulted in reduced growth of the nase larvae - their body mass and length were lower compared with the fish fed Artemia sp. The fish fed the diet containing $16 \%$ fat had larger hepatocytes and both groups fed these artificial diets had larger hepatocytes fat droplets than the control fish. The liver ultrastructure of fish fed diets $\mathrm{B}$ and $\mathrm{C}$ showed considerable alterations compared with the fish fed the natural feed. In the control fish, hepatocytes nuclei were large and oval (diameter $4.8 \mu \mathrm{m}$ ) and numerous milochondria were present in the hepatocytes cytoplasm. Many hepatocytes of the control fish had fat droplets of $0.8-2.8 \mu \mathrm{m}$ diameter were located near the glycogen (Figure 1a). The livers of the fish fed both commercial diets showed similar anomalies: the hepatocytes nuclei were smaller (diameter $4.6 \mu \mathrm{m}$ ), atrophic, located at the cell perimeter, and some of them lacked nucleoli (Figure 1c). The RER cisterns werc considerably less abundant compared with the control. The mitochondria were also less numerous, and were elongated with a strongly condensed matrix. The glycogen rosettes were reduced, while the lipid vacuoles, much larger compared with the control (Figure $1 \mathrm{~b}, \mathrm{c})$. The hepatocytes cytoplasm of fish fed the diet containing $7 \%$ fat showed large fat droplets (diameter 0.9-7.4 $\mu \mathrm{m}$ ) of low clectron density (Figure Ib), while in the hepatocytes of larvac fed the feed containing $16 \%$ fat the cytoplasm also contained large fat droplets (diameter 2.5-9.4 $\mu \mathrm{m}$ ) but showed high electron density (Figure 1c). Moreover, increased proliferation of peroxisomes was observed in the hepatocytes of fish fed experimental diets, while in the control, peroxisomes were rare. 
TABLE 1

Fatty acid composition in natural and artificial feeds

\begin{tabular}{lccccccccc}
\hline & \multicolumn{1}{c}{ Fatty acids } \\
\cline { 2 - 10 } Diets & \multirow{2}{*}{ SFA } & \multirow{2}{*}{ MUFA } & PUFA & $\begin{array}{c}\text { n-3 } \\
\text { PUFA }\end{array}$ & $\begin{array}{c}\text { n-6 } \\
\text { PUFA }\end{array}$ & n-3/n-6 & $\begin{array}{c}\text { C20:4 } \\
\text { n-6 }\end{array}$ & $\begin{array}{c}\text { C20:5 } \\
\text { n-3 }\end{array}$ & $\begin{array}{c}\text { C20:5 } \\
\text { n-3 }\end{array}$ \\
\hline Artemia & 18.1 & 41.8 & 35.0 & 21.1 & 14.0 & 1.48 & 2.4 & 13.1 & - \\
B & 25.2 & 27.0 & 46.3 & 24.8 & 21.5 & 1.15 & 0.9 & 6.6 & 12.2 \\
C & 25.4 & 28.5 & 44.5 & 25.2 & 19.3 & 1.31 & 1.3 & 7.1 & 12.2 \\
\hline
\end{tabular}

TABLE 2

Survival, growth, and morphometric parameters of hepatocytes of fish fed diets of various lipid contents

\begin{tabular}{|c|c|c|c|c|c|}
\hline \multirow{2}{*}{ Parameter } & \multicolumn{3}{|c|}{ Experimental groups } & \multirow{2}{*}{ SE pooled } & \multirow{2}{*}{$P$} \\
\hline & $\mathrm{A}$ & $\mathrm{B}$ & $\mathrm{C}$ & & \\
\hline Survival, \% & 91 & 83 & 79 & 2.8021 & 0.1370 \\
\hline Body mass increase, $\mathrm{g}$ & $0.568^{\mathrm{a}}$ & $0.369^{b}$ & $0.481^{\mathrm{c}}$ & 0.0282 & 0.0001 \\
\hline Total body length (LT), mm & $36.81^{\mathrm{a}}$ & $26.40^{\mathrm{b}}$ & $22.33^{c}$ & 0.9363 & 0.0000 \\
\hline Hepatocyte area, $\mu \mathrm{m}^{2}$ & $411.8^{3}$ & $483.67^{a}$ & $511.67^{b}$ & 28.6679 & 0.0463 \\
\hline
\end{tabular}
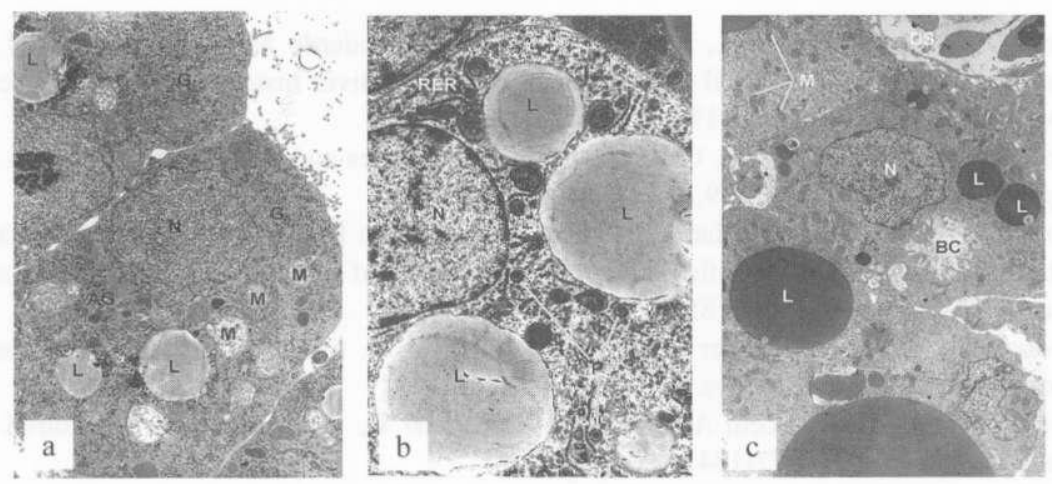

Figure 1. Ultrastructure of the hepatocytes of nase fed for 60 days: a. natural food $\times 4000$, b. $7 \%$ lipid feed $\times 5000$, c. $16 \%$ lipid feed $\times 2600$ (aberrations: G-glycogen, M-mitochondria, L-lipid droplet, AG-Golgi complex, N-nucleus, P-peroxisomes, RER-rough endoplasmic reticulum

\section{DISCUSSION}

Replacement of the natural feed with the experimental diets resulted in reduced survival and growth, and caused pathological changes in the liver (Table 2). Feeding of fish with Artemia supported the store of glycogen, the most easily available source of energy, in hepatocytes. The mitochondrial ultrastructure also shows that oxidative processes in mitochondrial respiration were more intense in Artemia-fed fish. Moreover, the hepatocytes of fish fed 7 and $16 \%$ fat diets showed abundant peroxisomes. These structures contain oxidative enzymes that participate in oxidation of many compounds, especially in $\beta$-oxidation of long-chain and shorter-chain fatty 
acids (Osmundsen et al., 1991). The presence of peroxisomes near the fat droplets also suggests their role in fatty acid degradation. In freshwater fish, peroxisome proliferation is probably induced by the activated enzymes of fatty acid metabolism (Ciancio and Cajaraville, 2000). The content of long-chain PUFA, particularly of C 22:6n-3 acid in commercial feeds might have also caused excessive fatty acid metabolism of organelles. The adverse effect of these fatty acids on larval growth of fish was also observed in Clarias gariepinus (Verreth et al., 1994). The livers of fish fed the $16 \%$ fat diet showed steatosis caused by excessive or unbalanced lipid uptake from diet, which resulted in lipid droplets accumulation (triglycerides), and increase in hepatocytes volume (Spisni et al., 1998). This was also confirmed by the high electron density of fat that was not metabolized but stored as triglycerides (Kestemont et al., 2001). The presented study indicate that a $16 \%$ fat level in feed, excessive supply of 22-carbon PUFA, and insufficient amount of MUFA may disturb lipid homeostasis in hepatocytes of freshwater fish, and adversely affect fish growth.

\section{REFERENCES}

Caballero M.J., López-Calero G., Socorro J., Roo F.J., Izquierdo M.S., Férnandez A.J., 1999. Combined effect of lipid level and fish meal quality on liver histology of gilthead seabream (Sparus aurata). Aquaculture 179, 277-290)

Ciancio I., Cajaraville M.P., 2000. Cell biology of peroxisomes and their characteristics in aquatic organisms. Int. Rev. Cytol. 199, 201-293

Kestemont P., Vandeloise F., Mélard Ch., Fontaine P., Brown P.B., 2001. Growth and nutritional status of Eurasian perch Perca fluviatilis fed graded levels of dietary lipids with or without added cthoxyquin. Aquaculture 203, 85-99

Osmundsen H., Bremer J., Weber J.-M., Brichon G., 1991. Metabolic aspects of peroxisomal $\beta$-oxidation. Biochem. Biophys. Acta 1085, 141-158

Spisni E., Tugnoli M., Ponticelli A., Mordenti T., Tomasi V., 1998. Steatosis in cultured marine tcleost. J. Fish Dis. 21, 177-184

Tacon A.G.J., 1996. Lipid nutritional pathology in farmed fish. Arch. Anim. Nutr. 49, 33-39

Verreth J., Coppoolse J., Segner 11., 1994. The effect of low HUFA- and high HUFA-enriched Artemia, fed at different feeding levels, on growth, survival, tissue fatty acids and liver histology of Clarias gariepinus larvae. Aquaculture 126, 137-150

\section{STRESZCZFNIE}

\section{Wplyw zawartości kwasów thuszczowych i tłuszczu w diecie na morfologiczne zmiany} w wątrobie larw świnki (Chondrostoma nasus L.)

Badano wpływ żywienia larw świnki (Chondrostoma nasus L.) paszami o zwiçkszoncj. $\mathrm{w}$ porównaniu $\mathrm{z}$ pokarmem naturalnym, zawartości tłuszczu i wielonienasyconych kwasów thuszczowych na ich wzrost i przeżywalność oraz stan morfologiczny wątroby. Stwierdzono, że 16\% zawartość tłuszczu w mieszankach, oraz. nadmierna podaż 22-węglowych PUFA i niedobór MUFA w paszy dla larw ryb słodkowodnych może wpływać na zakłócenie homeostazy przemiany lipidowcj w hepatocytach, a także zmnicjszać tempo wzrostu ryb. 